\title{
Bacteriological Analysis of Raw Beef Retailed in Selected Open Markets in Accra, Ghana
}

\author{
Michael Olu-Taiwo, Prince Obeng, and Akua Obeng Forson \\ Department of Medical Laboratory Science, School of Biomedical and Allied Health Sciences, College of Health Sciences, \\ University of Ghana, Legon, Accra, Ghana
}

Correspondence should be addressed to Akua Obeng Forson; obeng.akua@yahoo.com

Received 22 October 2020; Revised 5 February 2021; Accepted 4 May 2021; Published 13 May 2021

Academic Editor: Efstathios Giaouris

Copyright ( 2021 Michael Olu-Taiwo et al. This is an open access article distributed under the Creative Commons Attribution License, which permits unrestricted use, distribution, and reproduction in any medium, provided the original work is properly cited.

\begin{abstract}
Beef is an important and popular source of protein and nutrients. Constant monitoring and evaluation of the microbiological contamination is pertinent for its safety and quality. This study aimed to assess the bacteriological profiles and the bacterial loads in beef, as well as investigate food safety practices among beef retailers in selected open markets in Accra, Ghana. This was a crosssectional study with beef samples randomly purchased from six selected open markets in Accra metropolis. Beef samples were examined for total aerobic count (TAC) and total coliform count (TCC). Bacterial identification was performed by standard bacteriological methods and a well-structured questionnaire was administered to assess food safety and hygienic practices of beef retailers. Overall, mean TACs ranged between $2.2 \times 10^{3}$ and $1.3 \times 10^{4} \mathrm{CFU} / \mathrm{g}$, while mean TCCs ranged between $1.9 \times 10^{2}$ and $7.4 \times 10^{2} \mathrm{CFU} / \mathrm{g}$. Beef samples were mostly contaminated with Staphylococcus spp. (34\%), Klebsiella oxytoca (17\%), Enterobacter spp. (15\%), and Proteus vulgaris (3\%). This study showed varying levels of bacterial contamination of retailed beef sold in different Accra markets. According to the Health Protection Agency guidelines for assessing microbiological safety of ready-to-eat foods, our mean TACs were satisfactory, while mean TCCs were within borderline quality. The results of this study revealed that the majority of beef vended in open markets in Accra is contaminated with coliform and pathogenic bacteria. Therefore, more training in safe food handling and good hygiene practices is required for beef retailers. Conclusively, effective monitoring of the bacteriological profiles and bacterial loads of meat and meat products in abattoirs and points of sale should be established, since such a continuous monitoring system could help prevent potential health problems for consumers and provide information on possible sources of meat borne intoxication and infection.
\end{abstract}

\section{Introduction}

Beef (meat) is a nutritive-rich food that contributes vital proteins, vitamins, and minerals to higher bioavailability than other food sources $[1,2]$. In most developed countries, beef constitutes a significant part of the normal diet and contributes more than $15 \%$ energy, $40 \%$ protein, and $20 \%$ fat. The demand for meat in developing countries has continuously grown as the production and consumption pattern of meat increases with the availability of income [3]. However, meat has been found to be a prime vehicle for the dissemination of foodborne pathogens to humans. The water content activity of fresh meat and its neutral $\mathrm{pH}$ play a vital role in the growth of microbes. Beef may be susceptible to contamination at different stages of processing, from personnel and during transportation $[4,5]$. The incidence of beef contamination and related illnesses worldwide has led to an increase in public health concern related to meat safety in both developed and developing countries [6]. In 2015, a report by the World Health Organization (WHO) documented that 600 million foodborne illnesses were responsible for 420,000 deaths in 2010 [7]. Furthermore, in 2016, the Centers for Disease Control and Prevention [8] reported that a total of 839 cases of foodborne disease outbreaks cumulated in 14,972 illnesses, 794 hospitalizations, and 17 deaths with 18 food products. In Pakistan, the microbial load of raw meat at abattoirs and retail outlets in different areas of Lahore had been reported as a mean aerobic count of 7.15 , 
6.92, and $6.62 \log \mathrm{CFU} / \mathrm{cm}^{2}$ and 5.35, 5.42, and $4.84 \mathrm{log}$ $\mathrm{CFU} / \mathrm{cm}^{2}$ for beef, sheep, and goat meat at abattoirs and retail outlets, respectively, with a prevalence of $45 \%, 51 \%$, and $18 \%$ for Escherichia coli, Staphylococcus aureus, and Salmonella spp., respectively [9]. In Egypt, a study monitored the bacterial contamination during different stages of beef carcass preparation at an abattoir and found surface counts to exceed $10^{6} \mathrm{CFU} / \mathrm{cm}^{2}$ [10]. In India, a study determined the microbiological quality of meat collected from municipal slaughterhouses and retail meat shops revealed $29.7 \%$ of the samples had exceeded the legislative limit of $10^{4} \mathrm{CFU} / \mathrm{g}$, with varying prevalence for Escherichia coli (10\%), Staphylococcus aureus (8.3\%), and Salmonella spp. (5\%) [11]. In Ghana, a study determined the microbiological quality of fresh meat from retail outlets in the Northern Region of Ghana and revealed mean total aerobic counts of $5.74 \times 10^{6} \mathrm{CFU} / \mathrm{cm}^{2}, \quad 7.58 \times 10^{6} \mathrm{CFU} / \mathrm{cm}^{2}, \quad$ and $8.85 \times 10^{6} \mathrm{CFU} / \mathrm{cm}^{2}$ for morning, afternoon, and late afternoon samples, respectively [12]. However, there is a lack of periodic monitoring of raw meats and limited information on the bacteriological nature of meat and meat products in open markets. This study aimed to assess the bacteriological profiles and loads of raw beef sold in open markets in the Accra metropolis and to investigate food safety practices among beef retailers in order to provide additional information to inform policies to protect public health.

\section{Materials and Methods}

2.1. Study Area. The study was conducted in the Greater Accra Region which is the smallest among the 16 administrative regions in Ghana. It occupies a total land surface of $3,245 \mathrm{~km}^{2}$ or $1.4 \%$ of the total land area of Ghana. However, in terms of population, it is the second only to the Ashanti Region, with an estimated urban population of 2.5 million, accounting for $15.4 \%$ of Ghana's total population [13]. Accra metropolitan markets used for this study included Makola, Kaneshie, Agbogbloshie, Malata, Maamobi, and Nima markets.

2.2. Study Design and Sample Collection. This was a descriptive cross-sectional study of retailed beef in some open markets in the Accra metropolis (Figure $1(\mathrm{~A})$ ). One hundred (100) beef samples were randomly purchased from each of the six selected open markets within the Accra metropolis, Makola (10), Kaneshie (15), Agbogbloshie (20), Malata (25), Maamobi (10), and Nima (20) markets. Purchased beef samples were aseptically collected in sterile zip loc bags (Kolysen, China), sealed, and transported in an ice chest within 2 hours to the University of Ghana School of Biomedical and Allied Health Sciences Microbiology Laboratory for bacteriological analysis.

2.3. Survey Questionnaire. Additionally, a well-structured questionnaire was used to obtain data relevant to food safety awareness from retailers. The main areas of assessment were processing, storage, selling conditions, personal and environmental hygiene, and waste disposal as well as

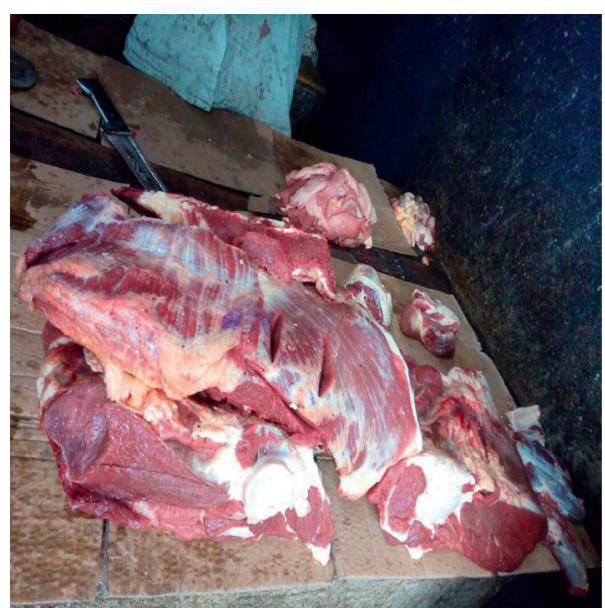

FIgURE 1: The typical state of a beef retail joint.

hygienic handling of used materials such as knives and water.

2.4. Bacteriological Analysis of Samples. Approximately $10 \mathrm{~g}$ of raw beef sample was added to $90 \mathrm{ml}$ of $0.1 \%$ buffered peptone water (Oxoid, UK) to prepare homogenate suspension in a stomacher bag (Seward, UK), followed by tenfold serial dilutions $\left(10^{-2}\right.$ to $\left.10^{-4}\right)$ as described by Clarence et al. [14]. An aliquot of $0.1 \mathrm{ml}$ from each serial dilution was inoculated onto plate count agar (Oxoid, UK), blood agar (Oxoid, UK), and MacConkey agar plates (Oxoid, UK), employing the spread plate method for total aerobic count (TAC) and total coliform count (TCC). Inoculation was done in triplicate and the plates were incubated at $37^{\circ} \mathrm{C}$ for $24-48$ hours. Enumeration of colonies took place on plate count agar (TAC) and MacConkey agar (TCC). Furthermore, dilutions that resulted in 30-300 colonies were considered countable and were included in the calculations. For bacteria identification purpose, 3-4 well-isolated colonies were obtained from primary cultures by subculturing and checking for purity onto MacConkey agar (Oxoid, UK) and blood agar (Oxoid, UK). The identification of pure culture colonies was based on colonial morphology, Gram staining, and biochemical reactions of triple sugar iron (TSI), oxidase, coagulase, citrate utilization, urease, and indole tests [15]. API 20E identification system (bioMerieux SA, Marcyl'Etoile, France) was also used to confirm the Gramnegative isolates.

2.5. Statistical Analysis. Bacterial counts were calculated as colony forming units per gram (CFU/g) and then converted into $\log 10$ values. Descriptive statistics were computed using the Microsoft Excel data analysis Fischer's exact chisquare and one-way ANOVA was analyzed using GraphPad Prism software, version 6, to find any statistical differences. Statistical significance was set at a $P$ value of $<$ 0.05 . 


\section{Results}

3.1. Bacteriological Counts. Overall, mean TACs of sampled beef ranged between $2.19 \times 10^{3}$ and $1.26 \times 10^{4} \mathrm{CFU} / \mathrm{g}$. Makola market had the highest mean TAC of $1.26 \times 10^{4} \mathrm{CFU} / \mathrm{g}$, while Nima market had the least mean TAC of $2.19 \times 10^{3} \mathrm{CFU} / \mathrm{g}$ (Table 1). Mean TCCs ranged between $1.9 \times 10^{2}$ and $7.4 \times 10^{2} \mathrm{CFU} / \mathrm{g}$. Maamobi market recorded the highest mean TCC of $7.4 \times 10^{2} \mathrm{CFU} / \mathrm{g}$, while Agbogbloshie market recorded the lowest mean TCC of $1.9 \times 10^{2} \mathrm{CFU} / \mathrm{g}$. There was a statistically significant difference between the mean TCCs of Maamobi and Agbogbloshie $(P<0.05)($ Table 1$)$.

\subsection{Prevalence of Bacteria Isolated from Various Market} Locations. Overall, a total of 110 bacterial isolates were recovered from sampled raw beef. The following bacteria were isolated: Acinetobacter spp. (1.8\%), Citrobacter spp. (1\%), Citrobacter diversus (8.2\%), Enterobacter spp. (15.5\%), Klebsiella spp. (13.6\%), Klebsiella oxytoca (17.3\%), Proteus vulgaris (2.7\%), Staphylococcus aureus (6.4\%), and Staphylococcus spp. (33.6\%).

The majority of bacteria identified were recovered from Agbogbloshie market $(23.6 \%$; 26), followed by Kaneshie $(20 \% ; 22)$, Nima $(20 \% ; 22)$, and Malata $(20 \% ; 22)$ markets. The least number of bacteria was isolated from Makola (8.2\%) and Maamobi markets (8.2\%), respectively (Table 2).

3.3. Demographics and Food Safety Awareness of Beef Retailers. Overall demographics, educational status, and food safety awareness of beef retailers are summarized in Table 3. With respect to what causes diseases, $80 \%$ were aware that microorganisms are responsible for diseases, while $18 \%$ said they were not aware of what causes diseases. In terms of inspection, sampling, and control by health authorities, $85 \%$ of the respondents claimed to have regular experience in the matters, while $8 \%$ rarely confront that issue. With regard to handwashing practices, $96 \%$ said they washed their hands after using the urinal and toilet, while $4 \%$ responded that such measures were not necessary.

\section{Discussion}

In this study, $60 \%$ of beef retailers were male and $40 \%$ were female, and while $65 \%$ of the retailers were within the age range of $16-35$ years, $35 \%$ were above 35 years. These findings are in agreement with a previous study by Adzitey et al. [16], where it was reported that butchering and retailing of beef were mostly practiced by the youth and middle-aged men, since the beef retailing business may be physically exhaustive. With regard to the education level of the beef retailers, primary education accounted for $50 \%$, followed by secondary (35\%), and tertiary (15\%) education, respectively. These findings are in agreement with a previous study by Adzitey et al. [17] conducted in the Northern Region of Ghana, which reported that $62 \%$ of respondents possessed an elementary form of education. The standard of education is pertinent to the awareness of beef safety practices, since it may influence retailers' acceptability of modern and more effective ways of safety practices as well as their adherence to strict hygienic and standard slaughtering practices. Bhandare et al. [18] have highlighted that most abattoir and retail beef workers in developing nations are mostly untrained and ignorant of hygienic standards that may alleviate bacterial contamination of beef products.

In the present study, $70 \%$ of beef retailers were licensed, whereas $25 \%$ did not possess any formal proof of evidence (e.g., professional license) or other legal binding state documents for doing business. Contrary to this study findings, Mcarthur-floyd et al. [19] in Madina, Accra, evaluated the practice of food safety among fast-food operators and reported the possession of health license by all fast-food operators surveyed. Furthermore, their findings revealed that the food inspection agencies are more stringent on ready-to-eat food sellers as compared to retailers of raw and uncooked food commodities such as beef retailers. Moreover, in our study, $87 \%$ of beef retailers admitted refrigerating beef products as a form of storage; however, $10 \%$ used freezers to store their meats. Most of the beef retailers admitted employing traditional or other nonconforming means such as salting and usage of antibiotics in order to preserve meat. With regard to the usage of water for cleaning purposes, $25 \%$ of beef retailers made use of well water for washing of meat, whereas this practice may be considered worrisome in terms of cross-transmission of meat with pathogenic bacteria. A study conducted by Ngwa and Chrysanthus [20] on the usage of well water revealed that this type of water is highly contaminated with bacteria of fecal origin such as Klebsiella spp. (95\%) and Escherichia coli (52\%), as well as pathogenic bacteria like Salmonella typhi $(32.5 \%)$. Additionally, salting as a means of preservation for meat is not only inadequate but also could predispose consumers to health risks such as high blood pressure and other cardiovascular diseases [21]. The combined retailing of beef along with other meats like chevron, chicken, and mutton may facilitate cross-contamination with microorganisms, due to the fact that contamination of meats may occur through different meat sources [22]. In this study, some retailers were not alarmed by the presence of increased bacterial loads in meat, since they believed that cooking would eradicate the organisms present. However, Prescott and Klein [23] have reported that most strains of Staphylococcus aureus implicated in staphylococcal enteritis are responsible for the synthesis of extracellular toxins, which are actually heat-resistant proteins that remain pathogenic when consumed even in cooked foods [23].

The general indicators of the microbiological food quality are TAC under favorable conditions that may enhance the multiplication of microorganisms [24]. In this study, an overall, mean TAC of beef in the surveyed markets in Accra ranged between $2.19 \times 10^{3}$ and $1.26 \times 10^{4} \mathrm{CFU} / \mathrm{g}$ (3.34-4.1 log CFU/g). These findings are comparable to another Ghanaian study by Soyiri et al. [25] which revealed a TAC range of $1.9 \times 10^{2}-2.3 \times 10^{4} \mathrm{CFU} / \mathrm{g}$ in retailed beef. In contrast, a higher mean TAC of $2.5 \times 10^{5}-2.25 \times 10^{8} \mathrm{CFU} / \mathrm{g}$ and $2.7 \times 10^{4}-2.0 \times 10^{8} \mathrm{CFU} / \mathrm{g}$ was reported by Jahan and Siddique [26] in Bangladesh and Erdem et al. [27] in Turkey, 
TABLE 1: Bacterial counts of beef from various markets.

\begin{tabular}{lccccc}
\hline Locations & $N$ & Mean TACCFU/g & Mean Log10 & Mean TCC CFU/g & Mean Log10 \\
\hline Mokola & 10 & $1.26 \times 10^{4}$ & 4.1 & 363 & 316 \\
Kanashie & 15 & $4.79 \times 10^{3}$ & 3.68 & 191 & 2.56 \\
Agbogloshie & 20 & $3.09 \times 10^{3}$ & 3.49 & 468 & $2.28^{*}$ \\
Malata & 25 & $3.0 \times 10^{3}$ & 3.47 & 741 & 2.67 \\
Maamobi & 10 & $4.9 \times 10^{3}$ & 3.69 & 372 & $2.87^{*}$ \\
Nima & 20 & $2.19 \times 10^{3}$ & 3.34 & & \\
Total & 100 & & & & \\
\hline
\end{tabular}

${ }^{*} P<0.05$.

TABLE 2: Occurrence of bacterial isolates from various markets.

\begin{tabular}{|c|c|c|c|c|}
\hline Markets & No. of samples taken & List of bacteria recovered & No. of isolates & Total \% \\
\hline Makola & 10 & $\begin{array}{l}\text { Klebsiella spp. } \\
\text { Klebsiella oxytoca } \\
\text { Proteus vulgaris } \\
\text { Staphylococcus aureus } \\
\text { Staphylococcus spp. }\end{array}$ & $\begin{array}{l}1 \\
5 \\
1 \\
1 \\
1\end{array}$ & $9(8.2)$ \\
\hline Kaneshie & 15 & $\begin{array}{l}\text { Citrobacter diversus } \\
\text { Enterobacter spp. } \\
\text { Klebsiella spp. } \\
\text { Klebsiella oxytoca } \\
\text { Proteus vulgaris } \\
\text { Staphylococcus aureus } \\
\text { Staphylococcus spp. }\end{array}$ & $\begin{array}{l}1 \\
2 \\
1 \\
9 \\
2 \\
4 \\
3\end{array}$ & $22(20)$ \\
\hline Agbogbloshie & 20 & $\begin{array}{l}\text { Citrobacter diversus } \\
\text { Enterobacter spp. } \\
\text { Klebsiella spp. } \\
\text { Klebsiella oxytoca } \\
\text { Staphylococcus aureus } \\
\text { Staphylococcus spp. }\end{array}$ & $\begin{array}{c}1 \\
5 \\
3 \\
2 \\
1 \\
14 \\
\end{array}$ & $26(23.6)$ \\
\hline Malata & 25 & $\begin{array}{l}\text { Citrobacter diversus } \\
\text { Enterobacter spp. } \\
\text { Klebsiella spp. } \\
\text { Klebsiella oxytoca } \\
\text { Staphylococcus aureus } \\
\text { Staphylococcus spp. }\end{array}$ & $\begin{array}{l}3 \\
1 \\
7 \\
2 \\
1 \\
8\end{array}$ & $22(20)$ \\
\hline Maamobi & 10 & $\begin{array}{l}\text { Acinetobacter spp. } \\
\text { Citrobacter diversus } \\
\text { Staphylococcus spp. }\end{array}$ & $\begin{array}{l}1 \\
2 \\
6\end{array}$ & $9(8.2)$ \\
\hline Nima & 20 & $\begin{array}{l}\text { Acinetobacter spp. } \\
\text { Citrobacter spp. } \\
\text { Citrobacter diversus } \\
\text { Enterobacter spp. } \\
\text { Klebsiella spp. } \\
\text { Klebsiella oxytoca } \\
\text { Staphylococcus spp. }\end{array}$ & $\begin{array}{l}1 \\
1 \\
3 \\
8 \\
3 \\
1 \\
5\end{array}$ & $22(20)$ \\
\hline
\end{tabular}

respectively. The International Commission on Microbiological Specification for Foods (ICMSF) has proposed that ready-to-eat foods with TAC between 0 and $10^{3} \mathrm{CFU} / \mathrm{g}$ are considered acceptable, within $10^{4}-10^{5} \mathrm{CFU} / \mathrm{g}$ are considered tolerable, and $\geq 10^{6} \mathrm{CFU} / \mathrm{g}$ are considered unacceptable [28]. Therefore, the level of contamination in this study could be considered tolerable based on the recommended standards. Our mean TCC of beef surveyed ranged between $1.9 \times 10^{2}$ and $7.4 \times 10^{2} \mathrm{CFU} / \mathrm{g}$. In a similar study by Koffi-Nevr et al. [29], a TCC of $1.6 \times 10^{2}-4.0 \times 10^{2} \mathrm{CFU} / \mathrm{g}$ was reported.
According to Health Protection Agency guidelines for assessing the microbiological safety of ready-to-eat foods [30], our mean TAC was satisfactory, while the mean TCC findings were within borderline quality and signals that the hygiene of practices of meat handling and processing along the meat production chain must be urgently improved. Therefore, considering the rather limited number of samples analyzed from selected locations and the varying environmental conditions for some retail joints, there is a certain degree of possibility that the bacterial loads could escalate to 
TABle 3: Demographics and food safety awareness of beef retailers.

\begin{tabular}{|c|c|c|}
\hline \multicolumn{2}{|l|}{ Demographics and food safety awareness } & \multirow{2}{*}{$\begin{array}{c}\text { Percentages } \\
60 \%\end{array}$} \\
\hline Sex & Male & \\
\hline sex & Female & $40 \%$ \\
\hline \multirow{3}{*}{ Age } & Below 16 & $0 \%$ \\
\hline & $16-35$ & $65 \%$ \\
\hline & Above 35 & $35 \%$ \\
\hline \multirow{3}{*}{ Educational status } & Primary & $35 \%$ \\
\hline & Secondary & $50 \%$ \\
\hline & Tertiary & $15 \%$ \\
\hline \multirow{3}{*}{ Duration of being in business } & Months & $25 \%$ \\
\hline & Years & $75 \%$ \\
\hline & Don't remember & $0 \%$ \\
\hline \multirow{3}{*}{ Health license } & Present & $70 \%$ \\
\hline & Absent & $25 \%$ \\
\hline & Don't know & $3 \%$ \\
\hline \multirow{3}{*}{ Temporary method for storage of beef } & Refrigerator & $87 \%$ \\
\hline & Freezer & $10 \%$ \\
\hline & None & $3 \%$ \\
\hline \multirow{3}{*}{ Maximum duration of storage } & 1 week & $79 \%$ \\
\hline & 1 month & $20 \%$ \\
\hline & More than month & 0 \\
\hline \multirow{2}{*}{ Washing of beef before vending } & Yes & $65 \%$ \\
\hline & No & $35 \%$ \\
\hline \multirow{3}{*}{ What type of water is used for washing } & Water & $90 \%$ \\
\hline & Water and soap & $0 \%$ \\
\hline & Antiseptic & $0 \%$ \\
\hline \multirow{3}{*}{ Water source for meat washing } & Tap water & $75 \%$ \\
\hline & Well water & $25 \%$ \\
\hline & Rainwater & $0 \%$ \\
\hline \multirow{3}{*}{ Is food safety important } & Yes & $97 \%$ \\
\hline & Not important & $0 \%$ \\
\hline & No response & $0 \%$ \\
\hline \multirow{3}{*}{ Source of food safety information } & Food safety course & $65 \%$ \\
\hline & Media & $8 \%$ \\
\hline & None & $20 \%$ \\
\hline \multirow{2}{*}{ Have you had any training on food safety } & Yes & $78 \%$ \\
\hline & No & $20 \%$ \\
\hline \multirow{3}{*}{ If yes, when? } & Months ago & $5 \%$ \\
\hline & Years ago & $75 \%$ \\
\hline & Don't remember & $20 \%$ \\
\hline
\end{tabular}

unsatisfactory levels if food safety parameters and hygienic status are not constantly monitored.

The predominant bacteria isolated in this study were Staphylococcus spp. (34\%), Klebsiella spp. (17\%), Klebsiella oxytoca (17\%), and Enterobacter spp. (15\%). This is in contrast to a previous study carried out on street-vended polyethylene-packaged pawpaw and watermelon in Accra which reported predominant bacteria isolated were Enterobacter spp. (33\%), Citrobacter spp. (20\%), and Klebsiella spp. (15.9\%) [31]. On the other hand, no Escherichia coli was isolated in both studies. Similarly, Jahan and Siddique [26] in Bangladesh reported the isolation of Staphylococcus spp. (26.7\%), Klebsiella spp. (20\%), Enterobacter spp. (10\%), and Salmonella spp. (13.3\%) in fresh beef. In contrast to this study findings, however, no Salmonella spp. was isolated. In another study by Chuku et al. [32] in Nigeria, researchers reported the isolation of Escherichia coli (83.6\%), Staphylococcus aureus (96.3\%), Staphylococcus epidermidis (88.8\%),
Salmonella spp. (42.5\%), Pseudomonas spp. (62.5\%), and Klebsiella spp. (80\%). The occurrence of bacteria in this study may have originated from the usage of contaminated well water used for washing the beef before retailing. In addition, bacteria may have gained access from the soil, since in some abattoir settings postslaughter processing is performed on the bare floor [27]. Bacterial isolates of the genus Klebsiella spp. and Enterobacter spp. are of clinical significance and may act as opportunistic pathogens that could cause infections of the lower respiratory and urinary tract system [33]. The occurrence of coagulase-positive Staphylococcus aureus may be attributed to insufficient hygiene practices and cross-contamination by handling meat and money with the same unwashed hands [34]. Staphylococcus aureus is known to cause food poisoning, which is often characterized by a sudden start of nausea, vomiting, stomach cramps, and diarrhea. Endotoxins that are produced when Staphylococcus aureus loads exceed $10^{5} \mathrm{CFU} / \mathrm{g}$ are the 
primary cause of food poisoning $[35,36]$. Globally, Staphylococcus aureus is one of the common causes of foodborne disease and staphylococcal intoxication could be attributed to improper handling of foods (meat) [37]. A previous study by Essayagh et al. [38] have reported an outbreak of food poisoning in Morocco at a family dinner, which resulted in 9 individuals being hospitalized [38] with clinical signs suggestive of Staphylococcus aureus foodborne poisoning.

Finally, in the present study, some markets were more contaminated in terms of the number and bacterial diversity. The difference in the level of beef contamination could be attributed to varying levels of hygienic practices of retailers in the various markets [39]. This encompasses the need to adhere to safety processing and handling practices, as well as strict sanitary standard operating procedures along the beef processing and production chain. Thus, Nima market was the market with the lowest mean TAC of $2.19 \times 10^{3} \mathrm{CFU} / \mathrm{g}$ and a mean TCC of $3.7 \times 10^{2} \mathrm{CFU} / \mathrm{g}$. Our observations in this market during the survey revealed that the beef retailers were relatively concentrated on one particular area of the market, which increased the likelihood that their meat product may have originated from the same abattoir. Moreover, most of the retailers in this market were largescale retailers with good storage facilities for the preservation of meat products.

\section{Conclusion}

This study showed varying levels of bacterial contamination of retailed beef sold in selected open markets within Accra metropolis. According to the Health Protection Agency guidelines for assessing microbiological safety of ready-toeat foods, our mean TACs were satisfactory, while mean TCCs were within borderline quality. The presence of different bacteriological profiles and loads still represents a public health hazard and signals the possible occurrence of foodborne intoxication and infection. Therefore, strict hygiene conditions, proper handling, and proper storage of meat products by retailers should be adhered to. Also, continuous monitoring of bacteriological profiles and loads in abattoirs and sales points should be implemented.

\section{Data Availability}

The datasets used are available upon reasonable demand.

\section{Ethical Approval}

The study was approved by the Ethics Committee of the School of Biomedical and Allied Health Sciences, College of Health Sciences, University of Ghana, Legon, Ethics Identification Number: SBAHS-MLS./10517975/SA/2017-2018. Participation was voluntary and consent was taken in accordance with the ethical committee's guidelines.

\section{Conflicts of Interest}

The authors declare that no conflicts of interest exist.

\section{Acknowledgments}

The authors would like to express their gratitude to all the beef retailers who volunteered to take part in this study.

\section{References}

[1] A. J. McAfee, E. M. McSorley, G. J. Cuskelly et al., "Red meat consumption: an overview of the risks and benefits," Meat Science, vol. 84, no. 1, pp. 1-13, 2010.

[2] C. R. Daniel, A. J. Cross, C. Koebnick, and R. Sinha, "Trends in meat consumption in the USA," Public Health Nutrition, vol. 14, no. 4, pp. 575-583, 2011.

[3] N. Myers and J. Kent, "New consumers: the influence of affluence on the environment," Proceedings of the National Academy of Sciences, vol. 100, no. 8, pp. 4963-4968, 2003.

[4] G. E. Nychas, P. N. Skandamis, C. C. Tassou, and C. Koutsoumanis, "Meat spoilage during distribution," Meat Science, vol. 78, no. 1-2, pp. 77-89, 2008.

[5] P. Walker, P. Rhubart-Berg, S. McKenzie, K. Kelling, and R. S. Lawrence, "Public health implications of meat production and consumption," Public Health Nutrition, vol. 8, no. 4, pp. 348-356, 2005.

[6] J. N. Sofos, "Challenges to meat safety in the 21 st century," Meat Science, vol. 78, no. 1-2, pp. 3-13, 2008.

[7] World Health Organization, WHO Estimates of the Global Burden of Foodborne Diseases. A Report by the Foodborne Disease Burden Epidemiology Reference Group 2007-2015, Geneva, Switzerland, 2015.

[8] Centers for Disease Control and Prevention, Surveillance for Foodborne Disease Outbreaks, United States: 2016, Annual Report, U.S. Department of Health And Human Services, Washington, DC, USA, 2018, https://www.cdc.gov/fdoss/pdf/ 2016_FoodBorneOutbreaks_508.pdf.

[9] M. U. D. Ahmad, A. Sarwar, M. I. Najeeb et al., "Assessment of microbial load of raw meat at abattoirs and retail outlets," The Journal of Animal \& Plant Sciences, vol. 23, no. 3, pp. 745-748, 2013.

[10] F. Khalafalla, F. Ali, A.-R. Hassan, and K. El-Feky, "Monitoring the bacterial contamination during different stages of beef carcass preparation at Beni-Suef abattoir, Egypt," Benha Veterinary Medical Journal, vol. 30, no. 1, pp. 51-58, 2016.

[11] P. Kumar, Y. Haribabu, and M. Y. Manjunath, "Microbiological quality of meat collected from municipal slaughter houses and retail meat shops from Hyderabad Karnataka region, India," APCBEE Procedia, vol. 8, pp. 364-369, 2014.

[12] A. K. Obeng, F. S. Johnson, and S. O. Appenteng, "Microbial quality of fresh meat from retail outlets in Tolon and Kumbungu districts of the northern region of Ghana," International Journal of Science and Technology, vol. 2, no. 6, pp. 423-428, 2013.

[13] T. H. Dzangmah, "Prospects and challenges of rental housing in greater Accra region," 2012, http://ir.knust.edu.gh/ bitstream/123456789/7611/1/DzangmahhenryTetteh.

[14] S. Y. Clarence, C. N. Obinna, and N. C. Shalom, "Assessment of bacteriological quality of ready to eat food (Meat pie) in Benin City Metropolis, Nigeria," African Journal of Microbiology Research, vol. 3, no. 6, pp. 390-395, 2009.

[15] E. Koneman, W. Winn, S. Allen, and S. Janda, Koneman's Color Atlas and Textbook of Diagnostic Microbiologypp. 367-373, Lippincott Williams \& Wilkins, Philadelphia, PA, USA, Sixth edition, 2006. 
[16] F. Adzitey, A. Abdul-aziz, and O. Moses, "Microbial quality of beef in the Yendi municipality of Ghana," Global Journal of Animal Scientific Research, vol. 2, no. 1, pp. 10-17, 2014.

[17] F. Adzitey, K. W. Sulleyman, and S. S. Mensah, "Knowledge and practices of meat safety by meat sellers in the kumasi metropolis of Ghana. Research \& reviews," Journal of Food Science And Technology, vol. 7, no. 2, pp. 34-41, 2018.

[18] S. G. Bhandare, A. M. Paturkar, V. S. Waskar, and R. J. Zende, "Prevalence of microorganisms of hygienic interest in an organized abattoir in Mumbai, India," The Journal of Infection in Developing Countries, vol. 4, no. 7, pp. 454-458, 2010.

[19] M. Mcarthur-floyd, V. Commey, and N. A. Boakye, "Evaluation of food safety among fast food operators in Madina, Accra," Food Science and Quality Management, vol. 54, no. 1989, pp. 18-25, 2016.

[20] N. R. Ngwa and N. Chrysanthus, "Bacteriological analysis of well water sources in the bambui student residential area," Journal of Water Resource and Protection, vol. 5, no. 11, pp. 1013-1017, 2013.

[21] S. Mohan and N. R. C. Campbell, "Salt and high blood pressure," Clinical Science, vol. 117, no. 1, pp. 1-11, 2009.

[22] E. Carrasco, A. Morales-Rueda, and R. M. García-Gimeno, "Cross-contamination and recontamination by Salmonella in foods: a review," Food Research International, vol. 45, no. 2, pp. 545-556, 2012.

[23] L. M. Prescott and P. H. Klein, Food and Industrial Microbiologypp. 978-981, McGraw-Hill, Boston, MA, USA, 5th edition, 2002.

[24] M. E. Nyenje, C. E. Odjadjare, N. F. Tanih, E. Green, and R. N. Ndip, "Foodborne pathogens recovered from ready-to-eat foods from roadside cafeterias and retail outlets in alice, eastern cape province, South Africa: public health implications," International Journal of Environmental Research and Public Health, vol. 9, no. 8, pp. 2608-2619, 2012.

[25] I. N. Soyiri, H. K. Agbogli, and J. Dongdem, "A pilot microbial assessment of beef sold in the Ashaiman market, a suburb of Accra, Ghana," African Journal of Food Agriculture Nutrition and Development, vol. 8, no. 1, pp. 91-103, 2008.

[26] F. Jahan and A. B. Siddique, "Bacteriological quality assessment of raw beef sold in sylhet sadar," The Agriculturists, vol. 13, no. 2, pp. 9-16, 2015.

[27] A. K. Erdem, D. Saglam, D. Ozer, and E. Ozclelik, "Microbiological quality of minced meat samples marketed in istanbul," YYU Veteriner Fakultesi Dergisi, vol. 25, no. 3, pp. 67-70, 2014.

[28] ICMSF (International Commission on Microbiological Specification for Food), Sampling for Microbiological Analysis, Principles and Specification Application, pp. 1-18, University of Toronto Press, Toronto, Canada, 1996.

[29] R. Koffi-Nevr, M. Koussemon, and S. O. Coulibaly, "Bacteriological quality of beef offered for retail sale in cote d'ivoire," American Journal of Food Technology, vol. 6, no. 9, pp. 835842, 2011.

[30] Health Protection Agency, Guidelines for Assessing the Microbiological Safety of Ready-To-Eat Foods, pp. 25-32, HPA, London, UK, 2009.

[31] M. Olu-Taiwo, M. D. Baakwa, and A. O. Forson, "Microbial quality of sliced pawpaw (Carica papaya) and watermelon (Citrullus lanatus) sold on some streets of Accra Metropolis, Ghana," International Journal of Microbiology, vol. 2021, Article ID 6695957, 8 pages, 2021

[32] A. Chuku, L. B Etim, G. A. Obande, and R. E. Asikong, "Bacteriological quality of fresh raw beef and chevon retailed in lafia metropolis, Nigeria," Journal of Microbiology Research, vol. 6, no. 2, pp. 29-34, 2016.

[33] M. N. Guentzel, "Escherichia, klebsiella, enterobacter, serratia, citrobacter and proteus," 1996, http://www.ncbi.nlm. nih.gov/books/NBK8035/.

[34] D. V. Adegunloye, "Microbial composition of the abattoir environment and its health implications on the quality of fresh cow meat sold in Akure, Ondo State, Nigeria," WIT Transactions on Ecology and the Environment, vol. 170, pp. 57-65, 2013.

[35] N. Balaban and A. Rasooly, "Staphylococcal enterotoxins," International Journal of Food Microbiology, vol. 61, no. 1, pp. 1-10, 2000.

[36] S. Derzelle, F. Dilasser, M. Duquenne, and V. Deperrois, "Differential temporal expression of the staphylococcal enterotoxins genes during cell growth," Food Microbiology, vol. 26, no. 8, 2009.

[37] J. Kadariya, T. C. Smith, and D. Thapaliya, "Staphylococcus aureus and staphylococcal food-borne disease: an ongoing challenge in public health," BioMed Research International, vol. 2014, Article ID 827965, 9 pages, 2014.

[38] T. Essayagh, M. Essayagh, A. El Rhafouli, M. Khouchoua, S. Essayagh, and A. Khattabi, "Foodborne outbreak, Meknes, Morocco: what we need to learn," Journal Of Tropical Disease, vol. 5, no. 3, pp. 1-4, 2017.

[39] M. Haileselassie, K. Adhana, and S. Kalayou, "Food safety knowledge and practices of abattoir and butchery shops and the microbial profile of meat in Mekelle City, Ethiopia," Asian Pacific Journal of Tropical Biomedicine, vol. 3, no. 5, pp. 407-412, 2013. 